\title{
Professor Tadeusz Orlowski - In Memory of a Pioneer in European Nephrology and Transplantation
}

\author{
August Heidland $^{\mathrm{a}}$ Leszek Paczek $^{\mathrm{b}}$

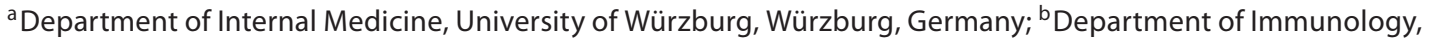 \\ Transplant Medicine and Internal Diseases, Medical University of Warsaw, Warsaw, Poland
}

Tadeusz Orlowski, 90, died of congestive heart failure on July 30th, 2008, in Warsaw. In him, Europe has lost a great authority in modern medicine and a committed researcher with a deep dedication to patient care. Orlowski was born on September 13th, 1917, in Kazan (Russia), as son of Prof. Witold Orlowski, the later founder of the Polish School of Internal Medicine. The young Tadeusz studied medicine during the Second World War in Warsaw and completed his physician diploma at the Medical Faculty of the Josef Pilsudski Polish Underground University in 1943. Under the Nazi Occupation he was active in the counter-espionage for the Polish Government in exile in London, adopting the nom de guerre of 'Spaga'. During the Warsaw Uprising he fought as a soldier of the Home Army (Polish Resistance Organisation), where he tended the wounded. For both of these life-threatening activities the patriot Orlowski received numerous decorations. Afterwards he worked as assistant at the Clinic of Internal Medicine of the University of Warsaw, chaired by his father. In 1963, at the age of 46, he advanced to professor ordinarius and in the same year took up the post of Head of the Clinic of Internal Medicine. From 1975 to 1987, Orlowski chaired the Institute of Transplantation, which he founded with the support of the Polish Academy of Sciences [1]. This leading transplantation institute - with all aspects of kidney, pancreas and liver transplantation - flourishes to this day under

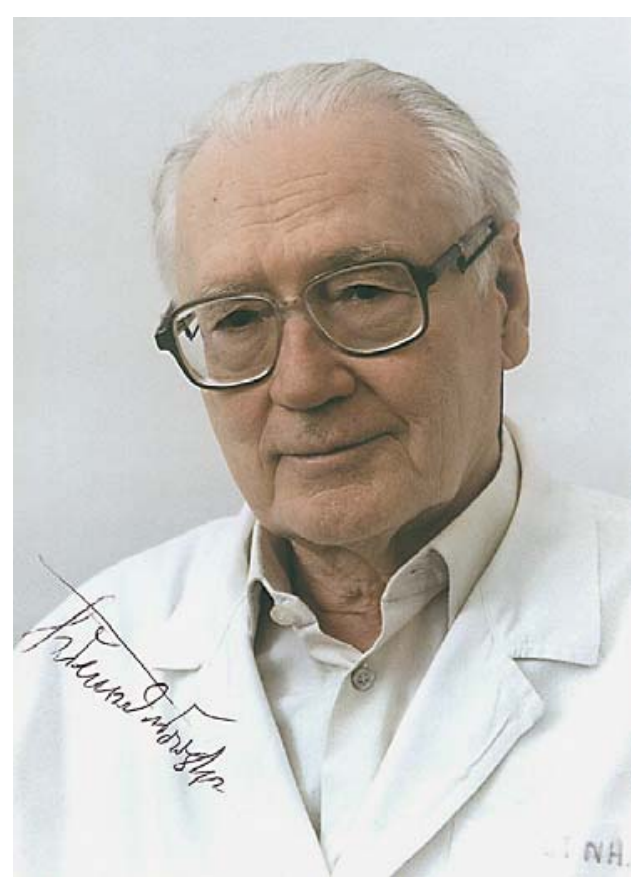

Prof. Tadeusz Orlowski [photo kindly provided by Prof. Zofia Wankowicz, Military Institute of Medicine, Warsaw, Poland].

\section{KARGER}

Fax +41613061234 E-Mail karger@karger.ch www.karger.com

\section{(C) 2009 S. Karger AG, Base}

$1420-4096 / 09 / 0324-0304 \$ 26.00 / 0$

Accessible online at:

www.karger.com/kbr
Prof. August Heidland

Department of Internal Medicine

University of Würzburg and KfH Kidney Centre Würzburg

Hans-Brandmann-Weg 1, DE-97080 Würzburg (Germany)

Tel. +49 931299 9672, Fax +49931299 9673, E-Mail August.Heidland@t-online.de 
the guidance of his successors: Professors M. Lao, W. Rowinski, M. Durlik, and L. Paczek. Under his chairmanship, more than 800 kidney transplantations were successfully performed [2]. In the year 2005, this number rose to 3,616 [3]. After retiring, Orlowski became contract professor at the Institute of Biocybernetics and Biotechnology in Warsaw, where he continued his research until his death.

For the treatment of acute renal failure, Orlowski introduced renal replacement therapies by peritoneal dialysis (together with Jan Nielubowicz) in 1953 and, 5 years later, hemodialysis [2]. He was also involved in the development of a Polish artificial kidney in the 1960s [4]. In 1966, a team led by him and Prof. J. Nielubowicz performed the first, successful cadaver kidney transplantation in Poland.

In 1954/55 Orlowski worked in Korea as Director of the Polish Red Cross Clinical Hospital in Hyn-Nam and Ham-Hyn. In the years 1959-1960, he was fellow of the Rockefeller Foundation at the Washington University of St. Louis. He became corresponding member of the Polish Academy of Sciences in 1964 and its ordinary member 7 years later. In the period 1972-1980 he served as First Deputy of the Scientific Secretary of the Polish Academy of Sciences and also headed the Nephrological Commission of the Pathophysiological Committee for more than 20 years. In these positions, he invited numerous researchers from Western countries and facilitated the scientific stays of Polish physicians abroad. Prof. Orlowski was member of the Boards of the European Dialysis and Transplant Association (EDTA) (1966-1969) and the International Society of Nephrology (1974-1976). He was on the editorial boards of Kidney International, Nephron, Clinical Nephrology, Excerpta Medica and the International Journal of Urology and Nephrology. From 1963 to 1994 he was Editor-in-Chief of the Polish Archives of Internal Medicine.

Orlowski's scientific work encompassed a broad spectrum. First of all, we owe him our gratitude for safeguarding the research protocols of Jewish physicians on the hunger disease in the Warsaw Ghetto [5]. After obtaining these records he buried them in the grounds of the hospital where his father worked and, at war's end, delivered the documents to Dr. Emil Apfelbaum, a survivor of the Warsaw Ghetto, who published them in 1946.

Prof. Orlowski's earliest scientific contributions (1951 and 1955) were related to primary glomerular diseases and congestive heart failure, where he also described the day-night rhythm of urine concentration and glomerular filtration rate [4]. During his stay in St. Louis in 1960, he published - together with Neal Bricker - two papers in the Journal of Clinical Investigation about the functional homogeneity of the nephron population in the experimentally diseased kidney of the dog. Later investigations dealt with renal function in the shock syndrome (1963) and mercury nephrosis (ISN, 1966). In investigations on the transplanted cadaver kidney, he showed a marked heterogeneity of the surviving nephron population by defects in tubular hydrogen ion secretion, a decreased tubular reabsorption of phosphate (Proc. EDTA, 1967) and a disturbed maximal transport rate of glucose (1969). Another interesting finding was a marked rise of plasma erythropoietin after kidney transplantation, in particular during rejection (1967). An important study concerned the uremic lung syndrome in dogs with experimental acute renal failure (1970). He demonstrated a decline of type II pneumocytes and a disruption of the lung surfactant system as major pathogenetic factors in the absence of overhydration and congestive heart failure. Together with W. Rowinski he demonstrated, in a subgroup of uremic patients, a rosette-inhibiting activity in the sera, which was positively influenced by dialysis (Proc. EDTA, 1972).

Beginning in the 1970s, Orlowski introduced immunotherapy for primary glomerular diseases (IgA nephropathy, 1990, and membranoproliferative glomerulonephritis, 1988), based on the combination of steroids, azathioprine and alkylating agents [6]. Kidney biopsies of these patients were performed routinely and evaluated in the renal pathology laboratory of the Transplantation Institute. After introduction of kidney transplantation in Warsaw, the scientific interest of Orlowski also included immune suppression in the kidney graft recipients as well as methods against acute and chronic graft rejection. For this purpose, he developed a rabbit antilymphocyte globulin as well as thymic hormones [7]. In the pre-cyclosporine era he introduced an immunosuppressive regimen with promethazine which resulted in substantial improvement of allograft survival [8].

Throughout the last two decades of his life, Orlowski's team worked with great commitment on new techniques for isolation, encapsulation and transplantation of islets of Langerhans in rats and pigs. As a result, numerous innovative articles were published in international journals [9].

The Orlowski School of Medicine had a fundamental impact on Polish and international nephrology and transplantation. Under his guidance, more than 20 habilitations were completed. Today many of his scholars occupy, or have occupied, prominent positions of nephrology. 
These include the Professors A. Sicinski, A. Gorski, M. Lao, L. Gradowska, Z. Wankowicz, L. Paczek, Z. Gaciong, and M. Durlik.

In recognition of his achievements, Orlowski was awarded an honorary membership in several Polish and foreign medical societies, the doctor honoris causa of the Medical Universities of Warsaw and Krakow as well as the Polish National Prize for his merits in transplantation.

Since 1972, Prof. August Heidland had the privilege to be frequently invited to Warsaw by Prof. Orlowski and to establish and maintain early contacts with the nephrologists of the Transplantation Centre. During this warm and long-standing friendship a close cooperation developed in particular with Prof. Leszek Paczek, the current head of the Orlowski Transplantation Centre. With the support of the Polish Academy of Sciences, Orlowski also organized visits of Heidland to other leading centres of nephrology in Poland, such as Katowice, Gdansk, Poznam, Wroclaw and Krakow.

Any description of Prof. Orlowski would be incomplete without mentioning his passion for mountain climbing [10]. As a young man he established some very difficult, new trails in the High Tatra Mountains, which are called Orlowski Routes. He followed the great classical climbing paradigms, i.e. no use of artificial aids during climbing. The difficulties of his routes surpassed all earlier climbing achievements in these mountains. He was regarded as the best Polish mountain climber of his generation.

Tadeusz Orlowski was an impressive personality. We all remember his upright, assertive and steadfast character. He was a pioneer who, under difficult conditions (the Iron Curtain), made a huge impact on nephrology and transplantation in Poland and on the international stage [11]. We will always honor his memory and never forget his legacy: 'In the mountains, I was always looking for the "impossible" routes and in medicine I was mostly intrigued by great unknowns. The mountains taught me that there are no impossibilities' (source: Elzieta KindlerJaworska, Tadeusz Orlowski's niece).

\section{Acknowledgements}

The authors would like to thank Mrs. Elzieta Kindler-Jaworska for the valuable information she provided during the drafting of this paper.

\section{References}

1 Kokot F, Heidland A: Laudatio: Professor Tadeusz Orlowski, 80 years. Nephrol Dial Transplant 1998;13:1308-1309.

2 Rutkowski B, Czekalski S, Lao M, Kokot F: Development of renal replacement therapy in Poland. J Nephol 2006;19(suppl 10):S159S164.

3 Paczek L, Durlik M, Gorski A, Krawczyk M, Szmidt J, Lao M, Walaszewski J, Rowinski W, Orlowski T: Organ transplantation at the Medical University of Warsaw. Clin Transpl 2005;145-152.

4 Czekalski S, Rutkowski B: The history of nephrology in Poland. J Nephrol 2006;19(suppl 10):S150-S158.
5 Massry SG, Smogorzewski M: The hunger disease of the Warsaw Ghetto. Am J Nephrol 2002;22:197-201.

6 Smogorzweski MJ, Lao M, Gradowska L, Rowinska D, Rancewicz Z: Immunosuppressive therapy in glomerular diseases: major accomplishment of Tadeusz Orlowski and his school. Pol Arch Med Wewn 2009;119: 333-337.

7 Orlowski T, Gorski A, Rancewicz Z, et al: Efficacy of a new treatment for chronic rejection: thymic hormones with immunosuppression. Transplant Proc 1989;21:21612162 .
-8 Orlowski T, Gaciong Z, Paczek L: Promethazine: results of triple-drug immunosuppression. Transplant Proc 1987;19:2124-2125.

9 Antonsiak-Iwanska M, Sitarek E, Sabat M, Godlewska E, Kinasiewicz J, Werynski A: Isolation, banking, encapsulation and transplantation of different types of Langerhans islets. Pol Arch Intern Med 2009;119:311316.

10 Nyka J: Tadeusz Orlowski and his Tatra trails. Pol Arch Intern Med 2009;115:293295.

11 Görski A: My remembrance of Professor Tadeusz Orlowski. Pol Arch Intern Med 2009; 119:289-291. 